\title{
A educação teológica nas veredas do labirinto literário: Mythodologia dos contos de Jorge Luis Borges
}

\section{Versão Corrigida}

Tese entregue à Faculdade de Educação da Universidade de São Paulo para obtenção do título de Doutor em Educação.

Área de Concentração: Cultura, Organização e Educação

Orientadora: Profa. Dra Soraia Chung Saura 
Autorizo a reprodução e divulgação total ou parcial deste trabalho, por qualquer meio convencional ou eletrônico, para fins de estudo e pesquisa, desde que citada a fonte.

Catalogação na publicação

Serviço de Biblioteca e Documentação

Faculdade de Educação da Universidade de São Paulo

\section{Carvalho, Rogério Gonçalves de}

A educação teológica nas veredas do labirinto literário: Mythodologia dos contos de Jorge Luis Borges / Rogério Gonçalves de Carvalho; orientadora, Soraia Chung Saura. 2017

$267 \mathrm{f}$.

Tese (Doutorado em Educação) - Programa de Pós-Graduação em Educação, Universidade de São Paulo, 2017

Versão Corrigida

1. Educação teológica. 2. Literatura latino-americana. 3. Mythodologia. 4. Jorge Luis Borges. 5. Contos. 6. Ficções - Aleph.

I. Saura, Soraia Chung, orient. II. Título.

CDD 1. Ed. 304.881 